$\underline{\xi}=-m$

\title{
Amelorative effect of olive oil against hepatorenal toxicity of cefotaxime in albino rats
}

\author{
Ashraf A. A. Elkomy ${ }^{1 *}$, Mossad G. E. El Sayed ${ }^{2}$, Faten I. Elsayed ${ }^{3}$, Ahmed A. Abd El Atey ${ }^{4}$ \\ ${ }^{I}$ Professor and Head of Pharmacology, Department, Faculty of Veterinary Medicine, Benha University, Egypt \\ ${ }^{2}$ Professor of Pharmacology, Faculty of Veterinary Medicine, Benha University, Egypt \\ ${ }^{3}$ Lecturer of Pharmacology, Faculty of Veterinary Medicine, Benha University, Egypt \\ ${ }^{4}$ Vet Officer, Ministry of Defense, Egypt \\ *Corresponding author E-mail: omarjo75@gmail.com
}

\begin{abstract}
Due to great hazard effects of antibiotic the following study aimed to investigate the adverse effect of cefotaxime in biochemical, oxidative status and histological examination of Liver and kidney tissue as well as the protective effect of olive oil. Twenty four male Wister albino rats were randomly divided into main four groups including: - G (1): Served as control group and it includes six rats, they were administrated $0.5 \mathrm{ml}$ of saline orally for 14 consecutive days. $\mathrm{G}(2)$ : it includes six rats, they were administered $5 \mathrm{ml} / \mathrm{kg}$ olive oil orally for 14 consecutive days. G (3): it includes six rats, they were administrated $90 \mathrm{mg} / \mathrm{kg}$ body weight/twice daily of cefotaxime intramuscular for 14 consecutive days. G (4): it includes six rats, they were administered $5 \mathrm{ml} / \mathrm{kg}$ olive oil orally concurrently with $90 \mathrm{mg} / \mathrm{kg}$ body weight/twice daily of cefotaxime. Results revealed that cefotaxime induced significant increases in liver and kidney function parameters including AST, ALT, ALP. creatinine, and urea as well as decrease in albumin and total protein level. Moreover, marked an increase in malondialdehyde (MDA) and decreases in glutathione (GSH) and catalase (CAT) levels. that indicate oxidative stress levels expression in the hepatic and renal tissues following cefotaxime administration. On the beneficial side oral administration of olive oil at the dose $5 \mathrm{ml} / \mathrm{kg}$ for 14 days significantly mitigate theses toxic effects. So it is concluded that olive oil has great hepatorenal antioxidant effect.
\end{abstract}

Keywords: Cefotaxime; Olive Oil; Liver; Kidney.

\section{Introduction}

Cephalosporins are semisynthetic antibiotics derived from cephalosporin C, a natural antibiotic produced by the mould Cephalosporium acremonium. They are structurally and pharmacologically related to the penicillins. Like the penicillins, cephalosporins have a betalactam ring structure that interferes with synthesis of the bacterial cell wall and so are bactericidal. They are grouped into "generations" based on their spectrum of antimicrobial activity. Each generation has a broader spectrum of activity than the one before (Sweetman 2009). The third-generation cephalosporins have extended potency against gram negative bacteria but are generally less active against susceptible staphylococci (Kathleen 2004). Third Generation Parenteral Cephalosporins are distinguished by their high antibacterial activity and their broad resistance to beta-lactamases; they have particularly good activity against most Enterobacteriaceae Exceptions include Enterobacter and Serratia, Streptococci are highly susceptible, staphyloccci moderately susceptible, and enterococci are resistant .They include Cefmenoxime, Cefotaxime,Cefovecin, Ceftizoxime, Ceftriaxone, Ceftiofur, and Latamoxef (Giguère et al. 2013).

Cefotaxime is a third-generation cephalosporin antibiotic with a broad spectrum of activity against Gram-positive and Gram-negative aerobic and anaerobic bacteria. It is generally more active against Gram-negative bacteria than the first and second generation cephalosporins. Cefotaxime is highly stable in the presence of beta-lactamases produced by certain Gram-negative and Gram-positive bacteria (Plosker et al. 1998). It is used in the treatment of infections due to susceptible organisms, especially serious and life threatening infection including: brain abscess, endocarditis, gonorrhea, intensive care, Lyme disease, meningitis, peritonitis, pneumonia, septicemia, preoperative prophylaxis and typhoid fever (Vanzanten et al.2007, Sweetman 2009). The most common adverse effects associated with cefotaxime and other cephalosporins are hypersensitivity reaction including skin rashes, urticaria, eosinophilia, and anaphylaxis (Fujiwaki et al. 2008). Other side effects may include diarrhea, vomiting, nausea, pseudomembranous colitis and transient elevation in liver enzymes (O’Connor et al. 2004, Rivkin 2005).

Olive oil, is a vegetable product obtained from the mesocarp of the fruit of the olive tree by a process of cold pressing. The product of the first pressing of the olive is the extra virgin olive oil (EVOO), which is considered the gold standard of edible oils. The EVOO composition is rich in monounsaturated fatty acids (MUFAs, 55-83\%), mainly oleic acid (OA, C18: $1 \mathrm{n}-9$ ), followed by 4-20\% of polyunsaturated fatty acids (PUFAs), and 8-14\% of saturated fatty acids (SFAs). Olea europaea is well known for its antioxidant properties, hypotensive, hypoglycemic and cardiovascular, nephro and hepato protective effects. It was also known for its antimicrobial activity and anti inflammatory properties (Bitler 2005). Olive oil consumption is associated with a lower risk of heart disease and certain cancers including breast and colorectal cancer. There is important evidence that indicates that some of the components of EVOO, such as OA and polyphenols like HT, show protective effects on the liver in various experimental models, especially in cellular cultures and animal proto- 
cols(Pirozzi et al. 2016, Zhao et al. 2014). These components significantly diminish hepatic fibrogenesis (Magdaleno et al. 2017, Lee et al. 2016), liver steatosis (Martin et al. 2010).

Thus, this study was designed to investigate whether the Olive oil could ameliorate the cefotaxime-induced oxidative, biochemical and hematological damage in liver and kidney tissues.

\section{Materials and methods}

\subsection{Materials}

\subsubsection{Chemical}

Cefotaxime (claforan) was obtained as a patent preparation (sanofi company) this is an I/V and I/M therapy .It formulated as cefotaxime sodium, there are $250,500.1000 \mathrm{mg}$. It is given by intramuscular injection at dose rate of $90 \mathrm{mg} / \mathrm{kg}$ body weight/ twice daily previously described by (Soliman 2015).

Olive was purchased from local market (Al Azhar. Cairo. Egypt). Olive oil was given by gavages at a dose of $5 \mathrm{ml} / \mathrm{kg} / \mathrm{day}$ as described by (Abbas et al.2015).

\subsubsection{Experimental animals}

Twenty four wister albino rats weighting 200-250gm were used in this investigation. They were obtained from Animal house of faculty of veterinary medicine, benha university. They are fed on normal rodent diet and apply water ad libtum. Rats were left for week for acclimatization before the beginning of the experiment.

\subsection{Methods}

\subsubsection{Experimental design}

Rats were divided into 4 group: Group (1): Served as control group and it includes six rats, they were administrated $0.5 \mathrm{~m} 1$ of saline orally for 14 consecutive days. Group (2): it includes six rats, they were administered $5 \mathrm{ml} / \mathrm{kg}$ olive oil orally for 14 consecutive days. Group (3): it includes six rats, they were administrated $90 \mathrm{mg} / \mathrm{kg}$ body weight/twice daily of cefotaxime intramuscular for 14 consecutive days. Group (4): it includes six rats, they were administrated $5 \mathrm{ml} / \mathrm{kg}$ olive oil orally concurrently with $90 \mathrm{mg} / \mathrm{kg}$ body weight $/$ twice daily of cefotaxime intramuscular for 14 consecutive days.

\subsubsection{Blood samples}

After the end of the period of treatment all rats are scarified and blood samples were taken. Two blood samples were taken from each rats for both biochemical and hematological studies from median canthus of the eye. the first blood sample was collected without anticoagulant for separation of clear serum for biochemical analysis. These serum samples were used for biochemical analysis to determine, serum transaminases activities (AST and ALT), alkaline phosphatase (ALP), total protein, Albumin, blood creatinine, blood urea. the second sample of blood was collected in the test tube mixed with sodium Citrate $3.8 \%$ as anticoagulant, the sample was shaked several times to ensure mixing of blood with anticoagulant. These blood samples were used for haematological studies to determine erythrocytic count, total leucocytic count, hemoglobin concentration.

\subsubsection{Tissue samples}

After the end of the period of treatment all rats are scarified and tissue samples were taken from liver, kidney for both biochemical study of oxidative stress markers (MDA, CAT, GSH) and Histopathological studies.

\subsubsection{Serum biochemical analysis}

Serum was obtained by high speed centrifugation. Serum AST and ALT were determined colorimetrically using spectrophotometer using specific kits (Centronic company) according to (Reitman and Frankel 1957). Serum alkaline phosphatase was determined according to (Chariman 1983) by kits from (Centronic company). Colorimetric determination of serum creatinine was carried out using spectrophotometer according to (Folin 1934) using specific kits. Serum urea concentration was determined according to( March et al. 1965) by kits (Centronic company).

\subsubsection{Evaluation of oxidative stress markers}

Both kidneys and liver were taken immediately after scarification, washed in physiological saline. One kidney and half of the liver were preserved at $-80^{\circ} \mathrm{c}$ until preparation of tissue homogenate which used for assessment of (MDA, CAT and GSH) levels colorimetrically.

\subsubsection{Haematological studies}

Total erythrocytes and leucocytes were counted using the improved neubauer chambe, as diluting fluid according to the method described by (Natt and Herrick 1952).

\subsubsection{Histopathology studied}

Tissue samples were taken from the liver and kidney of rats in different groups and fixed in formalin solution $10 \%$ for twenty four hours. The obtained tissue sections were collected on glass slides, deparaffinized and stained by hematoxylin and eosin stain for routine examination through the light microscope (Banchroft et al. 1996). 


\subsection{Statistical analysis}

First, all data were tested for normality and homogeneity. Then, one way analysis of variance used to determine the statistical significance of differences among groups followed by Duncan's test as post hoc for making a multiple comparisons using the Statistical Package for Social science Software (Version 25, SPSS Inc., Chicago, IL, USA). The values were expressed as the mean \pm standard error of the mean. A significant difference was used at the 0.05 probability level.

\section{Results}

\subsection{Effect on blood biochemical parameters}

Intramuscular injection of Cefotaxime showed significant increase in serum, AST, ALT, ALP, Urea, creatinine and decrease in serum total protein, albumin compared with control group Table $(1,2)$, figure $(1,2)$. while it was found that Oral administration of olive oil at $(5 \mathrm{ml} / \mathrm{kg}$ body weight) concurrently with cefotaxime result in significant decrease in serum, AST, ALT, ALP Urea and creatinine and caused significant increase in total protein, albumin compared to cefotaxime treated group. This indicated that olive oil had hepatorenal protective effect against cefotaxime toxicity.

\subsection{Effect on oxidative stress biomarkers}

In the present study, there were substantial increases in MDA level along with dramatic decreases in GSH and CAT in the liver and kidney tissues of cefotaxime-intoxicated rats, indicating the presence of oxidative stress. while it was found that Oral administration of olive oil at $(5 \mathrm{ml} / \mathrm{kg}$ body weight) concurrently with cefotaxime result in significant decrease in MDA and caused significant increase in GSH and CAT compared to cefotaxime treated group Table $(3,4)$, Figure $(3,4)$.

\subsection{Haematological finding}

There was significant reduction in RBCs, $\mathrm{Hb}$, and and significant increase in WBCs following cefotaxime administration at the dose rate of $90 \mathrm{mg} / \mathrm{kg}$ body weight twice daily intramuscular for 14 days when compared to control group. In concurrent group (cefotaxime*olive oil, there was significant increase in RBCs, $\mathrm{Hb}$, and significant reduction in WBCs when compared to cefotaxime treated group. Table (5). Figure (5).

\subsection{Histopathological finding}

Histopathological alteration in Liver of cefotaxime treated rat showed inflammatory cells infiltration with dilatation in the portal vein, as well as periductal fibrosis with inflammatory cells infiltration surrounding the bile ducts ,There was diffuse kupffer cells proliferation in between the hepatocytes all over the parenchyma, Focal necrosis was detected in the parenchyma, associated with focal degeneration and necrobiotic changes in the area hepatocytes at the periphery of the lobules. On the other hand, histopathological effect of cefotaxime on hepatic tissues was also markedly improved by co-administration of olive oil and cefotaxime Figure $(6,7,8,9,10)$.while histopathologically, kidney of control group showing no histological alterations also this detected in group treated with olive oil while in case of cefotaxime treated rat, it showed that The cortical blood vessels were congested while the corticomedullary portion showed degeneration and necrobiotic changes in the lining epithelium of the tubules. on the other hand, Histopathological effect of Cefotaxime on renal tissues was also markedly improved by co-administration of olive oil and cefotaxime. all this illustrated in Figure $(11,12,13,14)$

Table 1: Effect of Oral Administration of Olive Oil at $5 \mathrm{ml} / \mathrm{Kg}$ Body Weight for Successive 14 Days Liver Function Parameters in Cefotaxime $(90 \mathrm{mg} / \mathrm{Kg}$ B.Wt. Twice Daily) Treated Rats. $(\mathrm{N}=6)$

\begin{tabular}{lllll}
\hline Parameters & Control & Olive oil & Cefotaxime & Concurrent Cefotaxime + Olive oil \\
\hline ALT & $58.11 \pm 3.94^{\mathrm{c}}$ & $56.27 \pm 2.73^{\mathrm{c}}$ & $116.52 \pm 1.16^{\mathrm{a}}$ & $72.80 \pm 1.39^{\mathrm{b}}$ \\
AST & $72.86 \pm 0.83^{\mathrm{c}}$ & $71.67 \pm 0.88^{\mathrm{c}}$ & $162.35 \pm 11.12^{\mathrm{a}}$ & $106.46 \pm 3.20^{\mathrm{b}}$ \\
ALP & $169.19 \pm 3.75^{\mathrm{c}}$ & $165.13 \pm 1.62^{\mathrm{c}}$ & $390.50 \pm 13.05^{\mathrm{a}}$ & $254.58 \pm 6.57^{\mathrm{b}}$ \\
\hline
\end{tabular}

Data are presented as (Mean \pm S.E). S.E $=$ Standard error.

Mean values with different superscript letters in the same column are significantly different at $(\mathrm{P}<0.05)$.

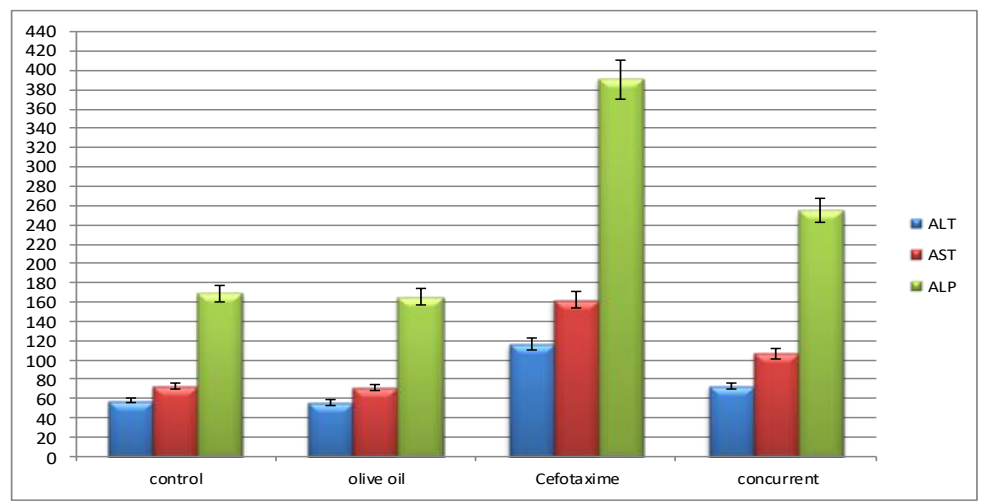

Fig. 1: Effect of Oral Administration of Olive Oil at $5 \mathrm{ml} / \mathrm{Kg}$ Body Weight for Successive 14 Days Liver Function Parameters in Cefotaxime $(90 \mathrm{mg} / \mathrm{Kg}$. B. Wt. Twice Daily) Treated Rats $(\mathrm{N}=6))$. 
Table 2: Effect of Oral Administration of Olive Oil at $5 \mathrm{ml} / \mathrm{Kg}$ Body Weight for Successive 14 Days on Kidney Function Parameters in Cefotaxime (90mg/Kg. B. Wt. Twice Daily) Treated Rats. (N=6).

\begin{tabular}{lllll}
\hline Parameters & Control & Olive oil & Cefotaxime & Concurrent Cefotaxime + Olive oil \\
\hline Albumin & $4.81 \pm 0.48^{\mathrm{a}}$ & $4.88 \pm 0.22^{\mathrm{a}}$ & $2.19 \pm 0.08^{\mathrm{c}}$ & $3.44 \pm 0.14^{\mathrm{b}}$ \\
Total protein & $10.97 \pm 0.20^{\mathrm{a}}$ & $10.34 \pm 0.30^{\mathrm{a}}$ & $4.54 \pm 0.18^{\mathrm{c}}$ & $7.93 \pm 0.23^{\mathrm{b}}$ \\
Urea & $32.87 \pm 1.17^{\mathrm{c}}$ & $32.23 \pm 1.77^{\mathrm{c}}$ & $54.23 \pm 3.21^{\mathrm{a}}$ & $43.43 \pm 1.22^{\mathrm{b}}$ \\
Creatinine & $0.97 \pm 0.09^{\mathrm{c}}$ & $0.94 \pm 0.06^{\mathrm{c}}$ & $1.94 \pm 0.04^{\mathrm{a}}$ & $1.31 \pm 0.06^{\mathrm{b}}$ \\
\hline
\end{tabular}

Data are presented as (Mean \pm S.E). S.E $=$ Standard error.

Mean values with different superscript letters in the same column are significantly different at $(\mathrm{P}<0.05)$

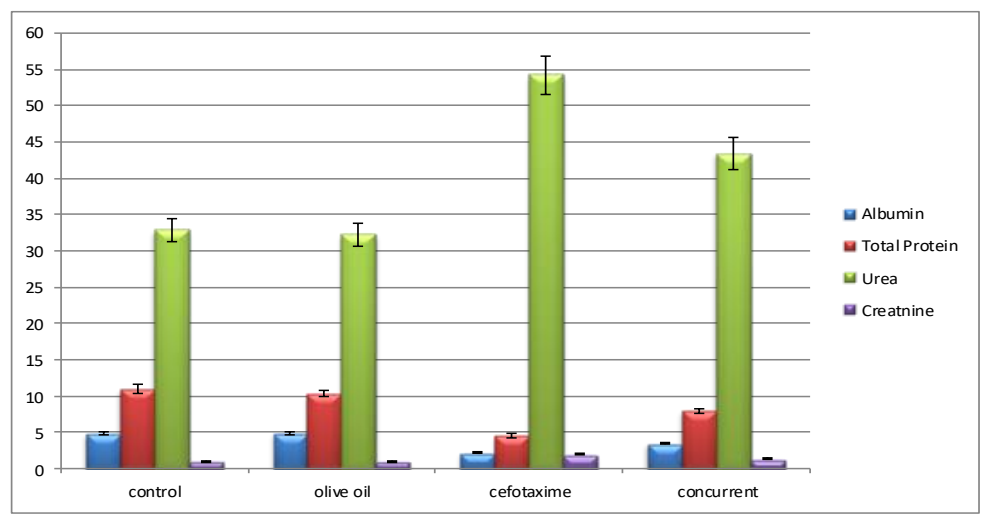

Fig. 2: Effect of Oral Administration of Olive Oil at $5 \mathrm{ml} / \mathrm{Kg}$ Body Weight for Successive 14 Days Kidney Function Parameters in Cefotaxime (90mg/Kg. B. Wt. Twice Daily) Treated Rats $(\mathrm{N}=6))$.

Table 3: Effect of Oral Administration of Olive Oil at $5 \mathrm{ml} / \mathrm{Kg}$ Body Weight for Successive 14 Days on Hepatic Oxidative Stress Biomarker in Kidney Levels in Cefotaxime (90mg/Kg. B. Wt. Twice Daily) Treated Rats. (N=6).

\begin{tabular}{lllll} 
Parameters & Control & Olive oil & Cefotaxime & Concurrent Cefotaxime + Olive oil \\
\hline MDA & $104.85 \pm 3.63^{\mathrm{c}}$ & $103.80 \pm 2.25^{\mathrm{c}}$ & $218.30 \pm 3.14^{\mathrm{a}}$ & $173.31 \pm 5.50^{\mathrm{b}}$ \\
CAT & $6.54 \pm 0.26^{\mathrm{a}}$ & $6.12 \pm 0.49^{\mathrm{a}}$ & $2.74 \pm 0.22^{\mathrm{c}}$ & $4.31 \pm 0.35^{\mathrm{b}}$ \\
GSH & $353.78 \pm 7.50^{\mathrm{a}}$ & $351.11 \pm 5.18^{\mathrm{a}}$ & $196.21 \pm 3.96^{\mathrm{c}}$ & $289.91 \pm 4.22^{\mathrm{b}}$ \\
\hline
\end{tabular}

Data are presented as (Mean \pm S.E). S.E = Standard error.

Mean values with different superscript letters in the same column are significantly different at $(\mathrm{P}<0.05)$.

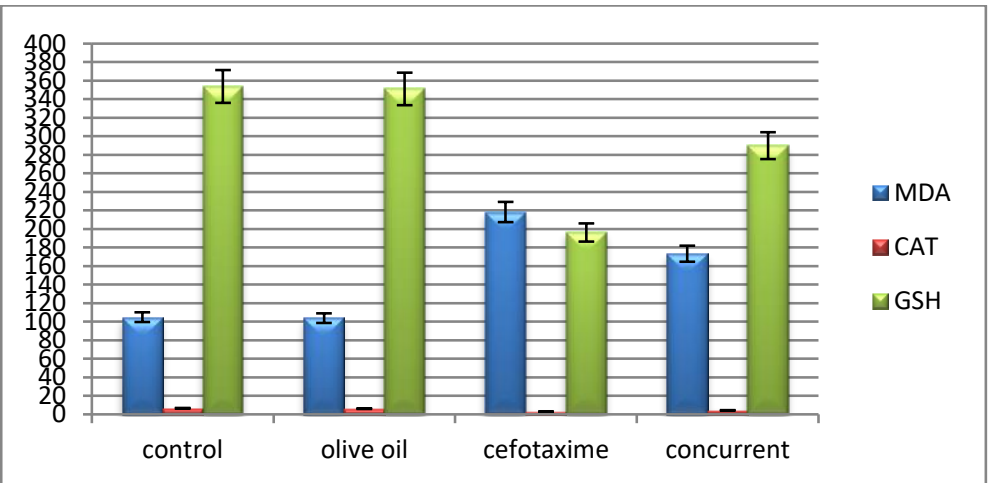

Fig. 3: Effect of Oral Administration of Olive Oil at $5 \mathrm{ml} / \mathrm{Kg}$ Body Weight for Successive 14 Days on Hepatic Oxidative Stress Biomarker Level in Cefotaxime $(90 \mathrm{mg} / \mathrm{Kg}$. B. Wt. Twice Daily) Treated Rats. (N=6).

Table 4: Effect of Oral Administration of Olive Oil at $5 \mathrm{ml} / \mathrm{Kg}$ Body Weight for Successive 14 Days on Renal Oxidative Stress Biomarker Levels in Cefotaxime (90mg/Kg. B. Wt. Twice Daily Treated Rats. (N=6).

\begin{tabular}{lllll}
\hline Parameters & Control & Olive oil & Cefotaxime & Concurrent Cefotaxime + Olive oil \\
MDA & $146.49 \pm 3.19^{\mathrm{c}}$ & $142.96 \pm 4.25^{\mathrm{c}}$ & $258.80 \pm 3.09^{\mathrm{a}}$ & $180.86 \pm 7.46^{\mathrm{b}}$ \\
CAT & $6.34 \pm 0.20^{\mathrm{a}}$ & $6.12 \pm 0.23^{\mathrm{a}}$ & $2.39 \pm 0.13^{\mathrm{c}}$ & $3.71 \pm 0.18^{\mathrm{b}}$ \\
GSH & $180.86 \pm 3.93^{\mathrm{a}}$ & $177.79 \pm 2.19^{\mathrm{a}}$ & $87.47 \pm 4.82^{\mathrm{c}}$ & $141.05 \pm 1.83^{\mathrm{b}}$ \\
\hline
\end{tabular}

Data are presented as (Mean \pm S.E). S.E $=$ Standard error.

Mean values with different superscript letters in the same column are significantly different at $(\mathrm{P}<0.05)$. 


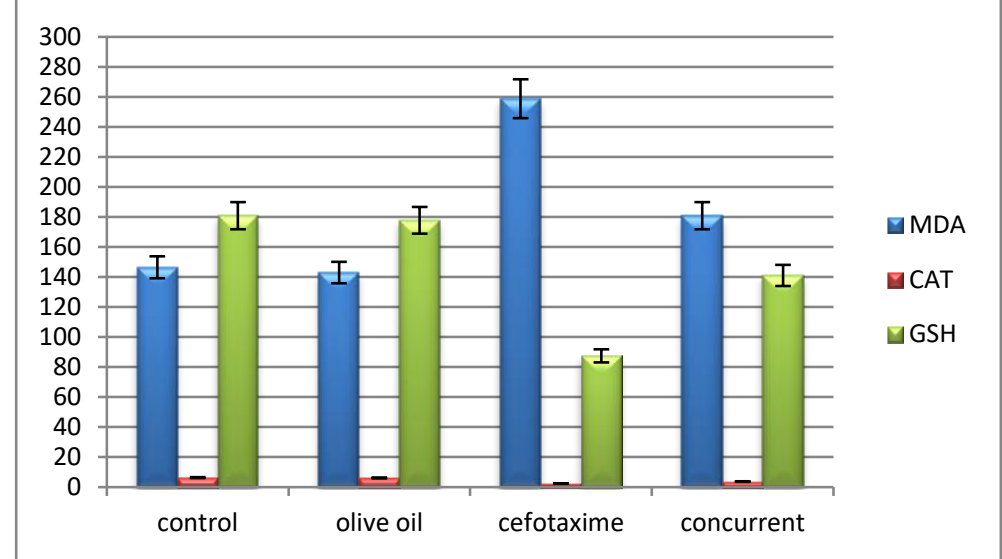

Fig. 4: Effect of Oral Administration of Olive Oil at $5 \mathrm{ml} / \mathrm{Kg}$ Body Weight for Successive 14 Days on Renal Oxidative Stress Biomarker Levels in Cefotaxime $(90 \mathrm{mg} / \mathrm{Kg}$. B. Wt. Twice Daily Treated Rats. (N=6).

Table 5: Effect of Oral Administration of Olive Oil at $5 \mathrm{ml} / \mathrm{Kg}$ Body Weight for Successive 14 Days on Hematological Parameters of Cefotaxime $(90 \mathrm{mg} / \mathrm{Kg}$. B. Wt. Twice Daily Treated Rats. $(\mathrm{N}=6)$

\begin{tabular}{lllll}
\hline Parameters & Control & Olive oil & Cefotaxime & Concurrent Cefotaxime + Olive oil \\
\hline RBCs $\left(10^{6} / \mathrm{cmm}\right)$ & $6.79 \pm 0.18^{\mathrm{a}}$ & $6.62 \pm 0.22^{\mathrm{a}}$ & $2.19 \pm 0.31^{\mathrm{c}}$ & $3.97 \pm 0.43^{\mathrm{b}}$ \\
WBCs $\left(10^{3} / \mathrm{cmm}\right)$ & $11.97 \pm 0.24^{\mathrm{c}}$ & $11.90 \pm 0.21^{\mathrm{c}}$ & $15.30 \pm 0.23^{\mathrm{a}}$ & $13.32 \pm 0.22^{\mathrm{b}}$ \\
$\mathrm{HB}(\mathrm{g} / \mathrm{dl})$ & $13.19 \pm 0.21^{\mathrm{a}}$ & $13.12 \pm 0.18^{\mathrm{a}}$ & $10.03 \pm 0.24^{\mathrm{c}}$ & $11.50 \pm 0.20^{\mathrm{b}}$ \\
\hline
\end{tabular}

Data are presented as (Mean \pm S.E). S.E $=$ Standard error.

Mean values with different superscript letters in the same column are significantly different at $(\mathrm{P}<0.05)$.

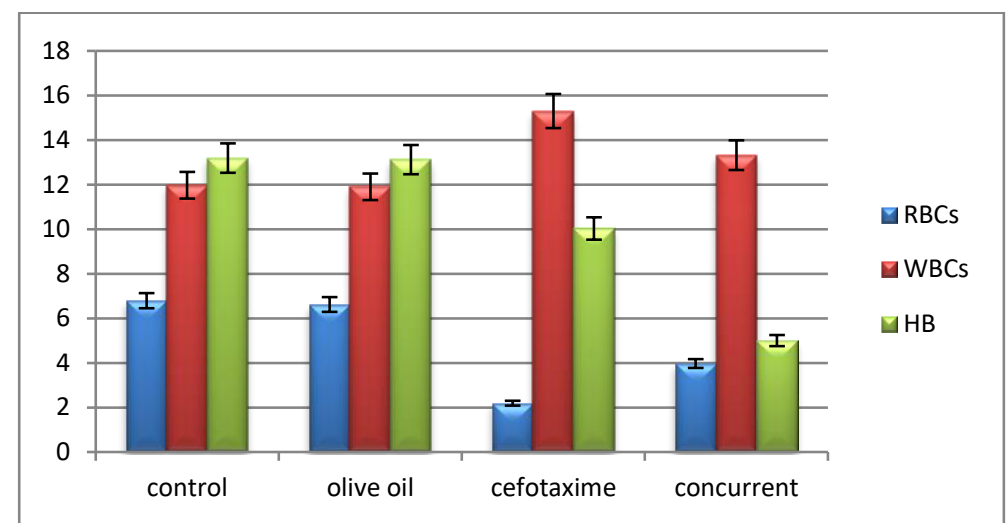

Fig. 5: Effect of Oral Administration of Olive Oil at $5 \mathrm{ml} / \mathrm{Kg}$ Body Weight for Successive 14 Days on Hematological Parameters of Cefotaxime $(90 \mathrm{mg} / \mathrm{Kg}$. B. Wt. Twice Daily Treated Rats. (N=6).

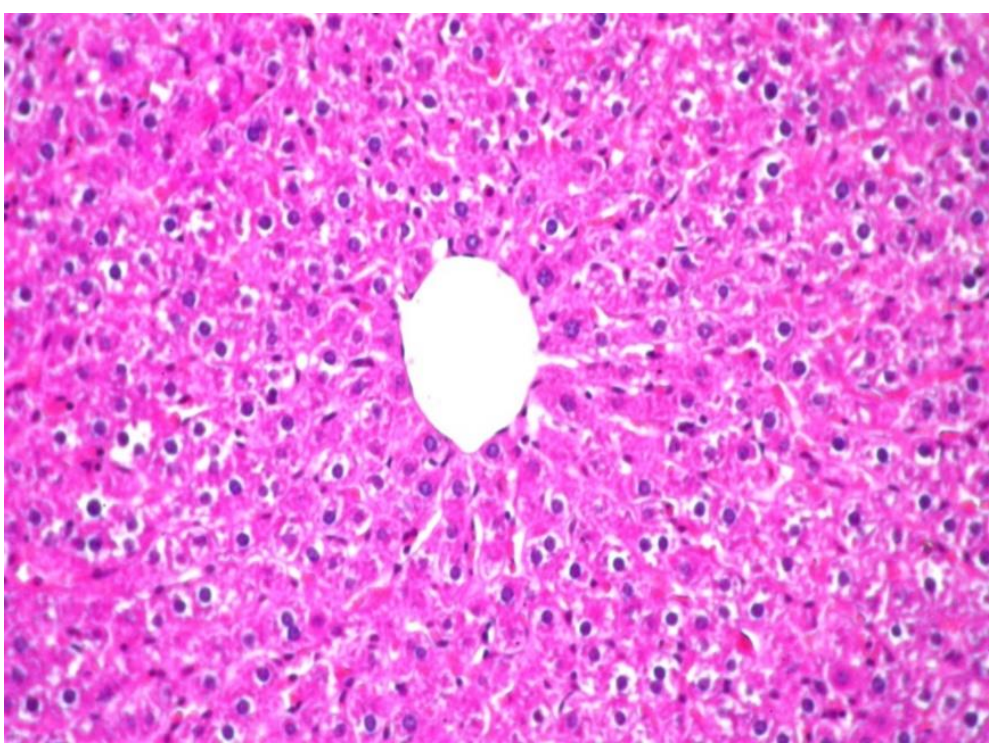

Fig. 6: Microscopical Picture of Liver of Control Group Showed No Histopathological Alteration and the Normal Histological Structure of the Central Vein and Surrounding Hepatocytes in the Parenchyma. 


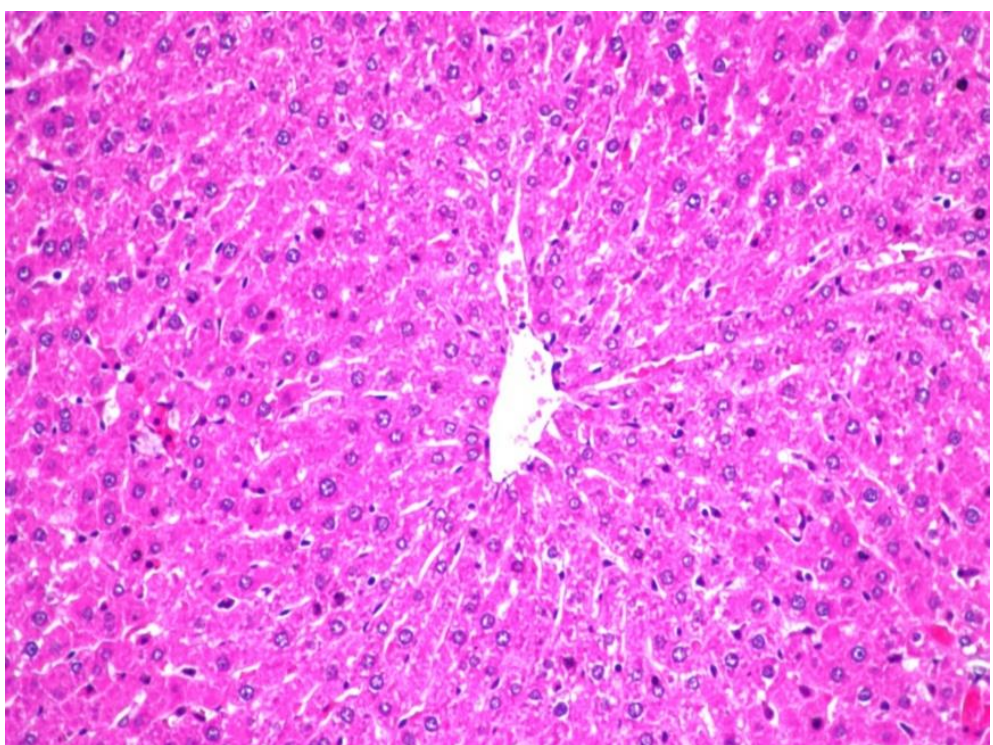

Fig. 7: Microscopical Picture of Liver of Olive Oil Treated Group Showed No Histopathological Alteration.

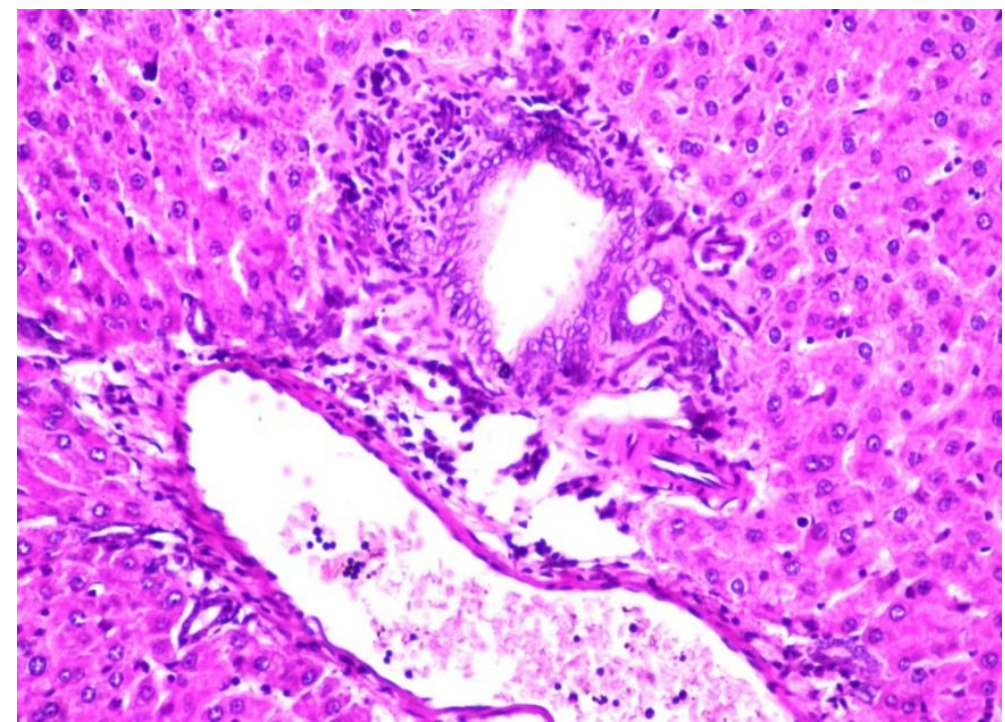

Fig. 8: Microscopical Picture of Liver of Cefotaxime Treated Group Showed Periductal Fibrosis with Inflammatory Cells Infiltration Surrounding the Bile Ducts.

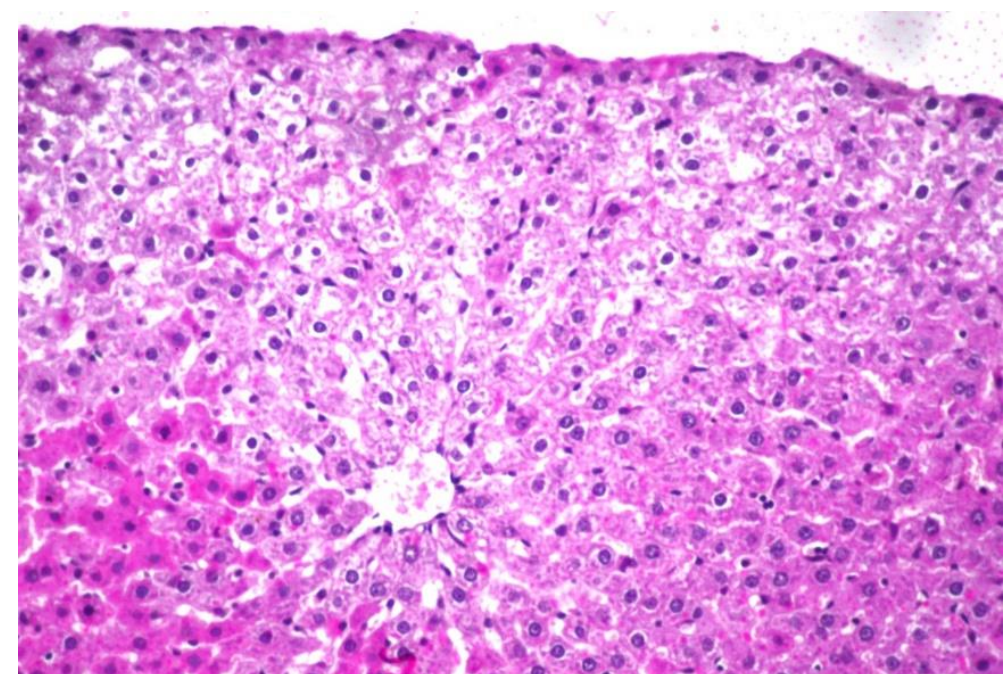

Fig. 9: Microscopical Picture of Liver of Cefotaxime Treated Group Showed Focal Degeneration and Necrobiotic Changes in the Area Hepatocytes at the Periphery of the Lobules. 


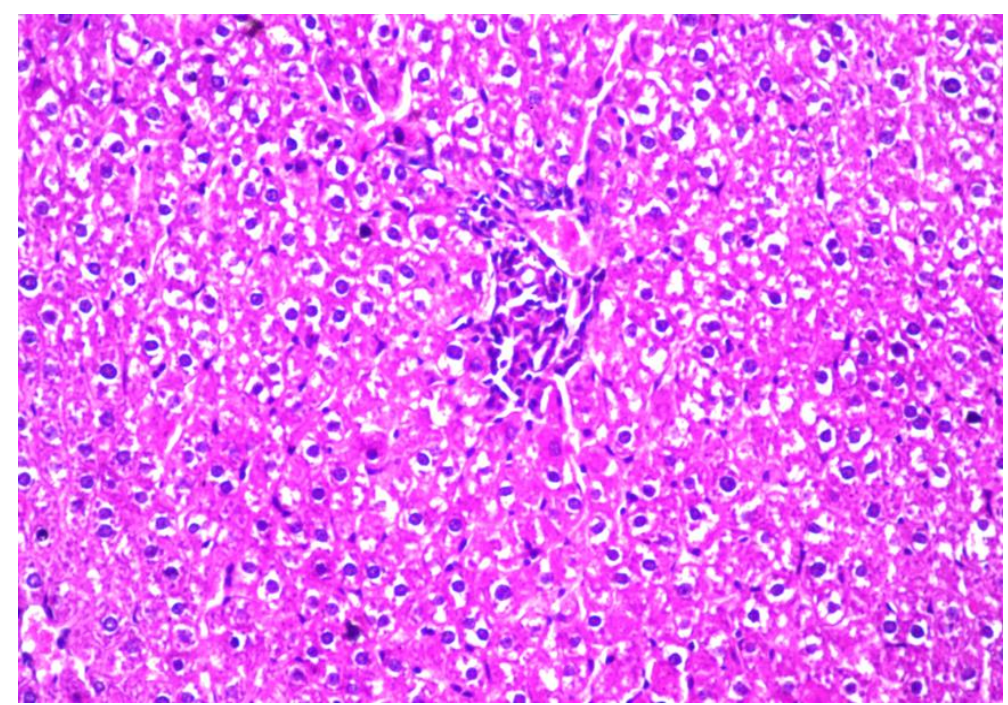

Fig. 10: Microscopical Picture of Liver of Concurrent Olive Oil and Cefotaxime Treated Group Showed That the Cortical Region Showed Few Inflammatory Cells Infiltration was Detected in the Portal Area While the Hepatocytes All Over the Parenchyma Showed Degenerative Change.

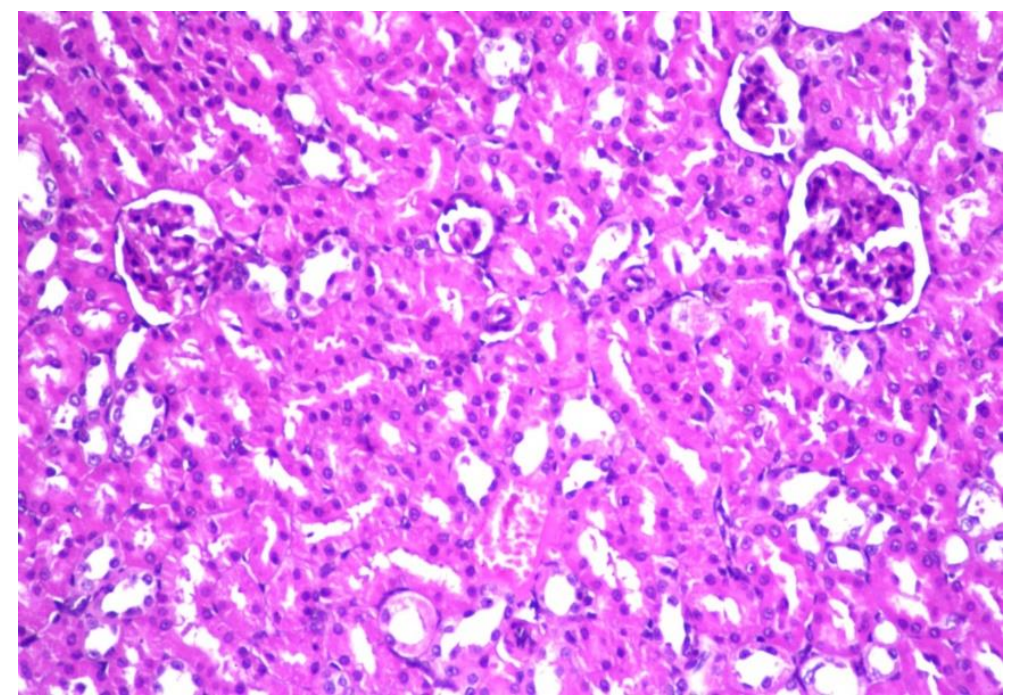

Fig. 11: Microscopical Picture of Kidney of Control Group Showed No Histopathological Alteration and the Normal Histological Structure of the Glomeruli and Tubules at the Cortex.

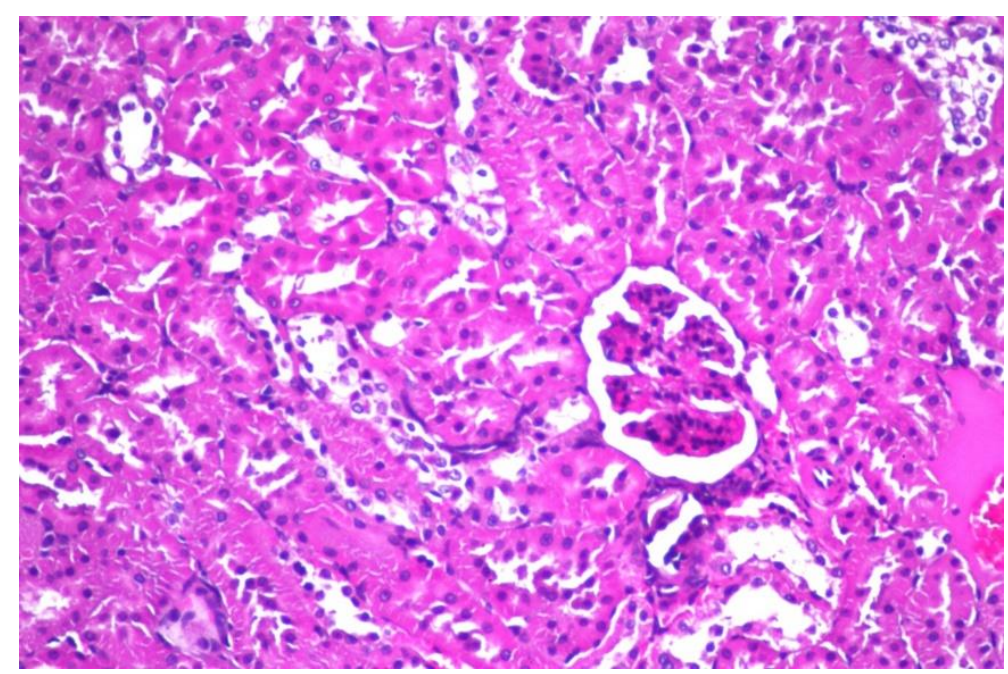

Fig. 12: Microscopical Picture of Kidney of Olive Oil Treated Group Showed No Histopathological Alteration. 


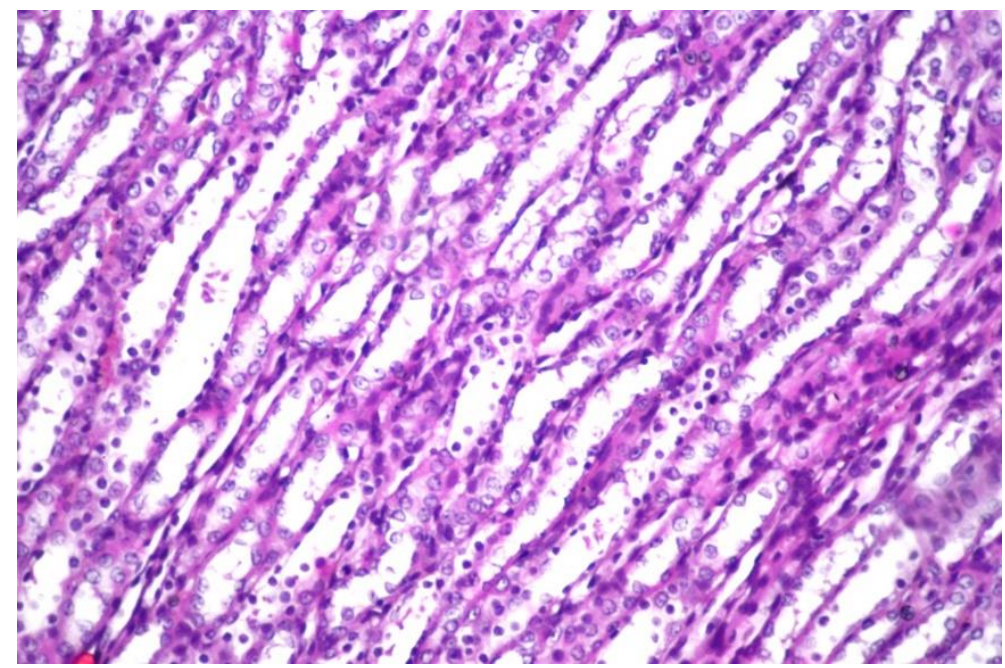

Fig. 13: Microscopical Picture of Kidney of Cefotaxime Treated Group Showed the Corticomedullary Portion Showed Degeneration and Necrobiotic Changes in the Lining Epithelium of the Tubules.

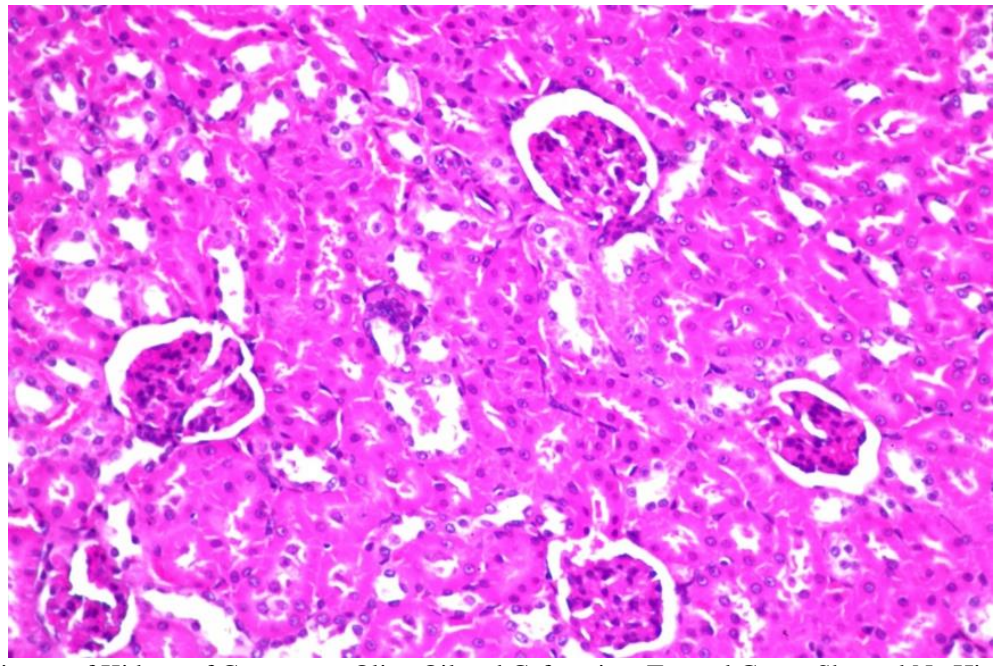

Fig. 14: Microscopical Picture of Kidney of Concurrent Olive Oil and Cefotaxime Treated Group Showed No Histopathological Alteration.

\section{Discussion}

Olive oil possesses anti-inflammatory, antiatherogenic activities and is a potent inhibitor of various reactive oxygen-generating enzymes. The present study was designed to investigate the hepatorenal protective effect of olive oil against cefotaxime toxicity.

\subsection{Effect on chemical biomarker}

Intramuscular injection of cefotxime at dose rate of $90 \mathrm{mg} / \mathrm{kg}$ body weight/twice daily for 14 days showed significant increase in serum aspartate aminotransferase, (AST) alanine aminotransferase (ALT) and alkaline phosphatase (ALP) compared to control group. This increase might be due to hepatocellular damage as fatty degeneration, fibrosis and impairment of liver functions causing leakage of liver enzymes into the circulation that is normally located in cytoplasm of hepatic cells. ALT, AST. ALP are considered the better indicator of functional efficiency of liver. They elevation may be attributed to the release of these enzymes from the cytoplasm into the blood circulation after rupture of the plasma membrane and cellular damage. Serum AST, ALT and ALP are biomarkers in the diagnosis of hepatic damage because they are released into the circulation after cellular damage. This result was in agreement with that reported by (ElMaddawy-Zeynab and Bogzil 2015) who reported intramuscular administration of cefotaxime sodium induced a significant $(\mathrm{P} \leq 0.05)$ increase in ALT, AST, ALP in rats.

Oral administraion of olive oil at ( $5 \mathrm{ml} / \mathrm{kg}$ body weight daily for 14days) followed by intramuscular injection of cefotxime at (90 mg/ kg body weight/twice daily for 14 days, result in significant decrease the levels of serum aspartate transaminase, alanine aminotransferase and alkaline phosphatase when compared with cefotxime group, suggesting that Olive oil protective activity might be due its effect against cellular leakage and loss of functional integrity of the cell membrane in hepatocyte. This result was in the same line with that reported by(Ghorbl et al. 2015) who found the protective effect of olive oil against hepatotoxicity induced by both aluminum and acrylamid in rats .Also agreed with data reported by( Khayyat 2016) who observed that extra virgin olive oil, when given in combination with paracetamol, significantly decreases the activity levels of AST, ALT and ALP in the serum of treated animals. Also agreed with data reported by (Abbas et al.2015) who found the Treatment of olive oil in combination with gentamicin reduced the serum level of AST, ALT to that of the gentamicin treated group On the other hand, cefotxime cause significant decrease in serum total protein. The decreased serum total protein might be due to liver fibrosis leading to reduction in the number of hepatocytes which in turn lead to defect of protein synthesis.

Oral administration of olive oil at $(5 \mathrm{ml} / \mathrm{kg}$ body weight daily for 14days) followed by intramuscular injection of cefotxime at (90 mg/ $\mathrm{kg}$ body weight/twice daily for 14 days showed increase in total protein and albumin, which indicated that olive oil prevented hepato- 
renal injury and improved physiology of liver and kidney by modulating cellular metabolism and regeneration. This resulted in the same context with that reported by( Necib et al.2014) who reported that Albumin and protein levels in mercuric chloride treated rats were decreased, but the co-administration of virgin olive oil with $\mathrm{HgCl} 2$ has produced a recovery toword the normal .

Urea, creatinine and electrolytes, were markers of kidney function(Thomas 2005). Our finding revealed that intramuscular administration of cefotxime at $(90 \mathrm{mg} / \mathrm{kg}$ body weight /twice daily for 14 days) resulted in a significant increase in serum of creatinine, urea. The obtained results were came in agreement with that obtained by(Ahmad et al. 2015) who reported the nephrotoxic effect of Amikacin ,cefotaxime and their combination. Rise in BUN and serum creatinine was highly significant when the amikacin was combined with cefotaxime in comparison with control groups. This is in agreement with(Soliman 2015) who reported that Cefotaxime in doses of 90 and $180 \mathrm{mg} / \mathrm{kg} \mathrm{b}$. wt. twice daily for 7 days caused a significant increase in creatinine and urea concentrations in the serum of treated rats. Oral administration of olive oil at $(5 \mathrm{ml} / \mathrm{kg}$ body weight daily for 14 days) followed by intramuscular injection of cefotxime at (90 mg / $\mathrm{kg}$ body weight /twice daily for 14days) resulted in a significant decrease of elevated serum creatinine and urea levels. Olive oil is considered as a renal protective substance which is used a lot years ago. This result is in the same context with that reported by (Mohammed et al. 2014) who reported Nigella sativa and virgin olive oils improved $(\mathrm{P}<0.05)$ renal dysfunction as assessed by significant decreased serum urea and creatinine concentrations of (cadmium+ olive oil) group. Also agreed with (Murtadha- Abed 2017) who reported that Olive oil administration significantly improved $(\mathrm{P}<0.05)$ renal dysfunction as assessed by significant decreased serum urea and creatinine concentrations of (ibuprofen+ olive oil) group. Also agreed with (Abbas et al.2015) who studied the protective effect of olive oil on gentamicin - induced nephrotoxicity by decreasing serum urea and creatinine.

\subsection{Effect on oxidative stress biomarkers}

Cell contain several antioxidant to prevent and repair cell damage, (CAT enzymatic antioxidant converts H202 to water and oxygen (weydert and Cullen 2010). GSH it is cofactor for several enzymes, it play a rule in detoxifying of hydrogen peroxide and lipid peroxidase through its action on glutathione peroxidase GSH px. It protects cell against apoptosis by interacting with pro-apoptotic signal path way (Masella et al. 2005) he imbalaree between oxidants(Reactive oxygen species ROS) and antioxidant in favor to oxidants is refered to oxidative stress (Birben et al. 2012), oxidative stress play great rule in many diseases .

Our finding revealed that intramuscular administration of cefotxime at dose rate of $90 \mathrm{mg} / \mathrm{kg}$ body weight /twice daily for 14 days induce oxidative stress in hepatic and renal tissues with evidenced by significant reduction in the CAT and GSH levels and elevation of the MDA concentration. The elevation in MDA level was attributed to oxidative stress and free radical generation through lipid peroxidation. Overproduction of free radicals induces an increase in lipid peroxidation (MDA) by destroying unsaturated fatty acids in the cell membrane and. This was in agreement with that reported by (Abd El Fadil et al. 2016, Abd El Fadil et al. 2018) who reported that gentamicin or cefotaxime groups evoked a significant inhibition in GSH, Cat, GPx, SOD and increase in MDA. These results supported by the histological finding of liver, kidney and testes of cefotaxime treated group.

Intersetinally, our results indicated that administration of olive oil at dose rate of $5 \mathrm{ml} / \mathrm{kg} \mathrm{b}$.wt for 14 days concurrently with cefotaxime protect renal and hepatic tissues from oxidative stress via improvement of the antioxidant status (CAT and GSH) and consequently reduced lipid peroxidation (MDA) concentration. these amelioration of oxidant/antioxidant status of renal and hepatic tissue by olive oil could be attributed to direct reduction of ROS generation and release. This was in agreement with that reported by(Mohammed et al. 2014)who reported that a significant decrease $(\mathrm{P}<0.05)$ in GSH concentration and a significant increase $(\mathrm{P}<0.05)$ in MDA concentration, CAT and SOD activities in tissues homogenates obtained from brain and kidney in the Cadmium treated group compared to control group. Nigella sativa and virgin olive oils groups nearly returned these values toward the normal. This was in agreement with( Mohammadian et al. 2018) who reported that olive oil in sodium arsenate-treated mice was effective in improving the MDA, GSH, and FRAP levels in liver tissues in comparison to the arsenate-treated mice $(\mathrm{P}<0.05)$. This was in agreement with (El Bohi et al. 2020) who reported mice exposed to IP injection of 5-hydroxymethylfurfural $(250 \mathrm{mg} / \mathrm{kg}$ bwt $)$ showed a significant decrease in their hepatic SOD , CAT and GSH activities content and significantly increased in hepatic MDA compared with the control group, while exposure of mice to both 5-HMFand Extra virgin olive oil increased the activities of both hepatic SOD , CAT and GSH and decrease the activity of MDA to the control level. On the other hand, EVOO alone significantly enhanced the activities of antioxidant enzymes to levels better than those of the control.

\subsection{Effect on haematological picture}

The results obtained from present study referred that administration of cefotaxime showed a significant decrease in red blood cells (RBCs) count, haemoglobin level (Hb), On the contrary, the level of white blood cells (WBCs) count significantly increased as compared to normal control. This results agreed with(El-Maddawy-Zeynab and Bogzil 2015 ) who showed that there was a significant reduction in Hb $\mathrm{g} \%, \mathrm{PCV} \%, \mathrm{RBCs}$ and WBCs counts and lymphocytes percent and a significant increase in neutrophils percent in rats treated with cefotaxime sodium at 2 nd \& 4th week of experiment. This was in agreement with that reported by (Williams-Cristin et al. 2009) reported that autoimmune haemolytic anemia was attributed to the second- and third-generation cephalosporins and that ceftriaxone induced haemolytic anemia was more fatal as it developed hemoglobinuria, hemolyzed blood specimens, and a decreased haemoglobin level.

On the beneficial side oral administration of olive oil before intramuscular injection of cefotxime, showed a significant improvement in haematological parameters this result was in harmony with that reported by (Ognjanovic et al. 1999) who reported that significant alterations of haematological values. Haematocrit values and haemoglobin concentrations were decreased (p0.01) as well as the number of red blood cells (p0.005) after acute, intraperitoneal (i.p.) administration of cadmium. Experiments with rats receiving olive oil in pretreatment show that olive oil prevents or mitigates anemia caused by cadmium. This was in agreement with that reported by (Aziz and Masad 2013) who reported that administration of vitamin $C$ and olive oil showed a significant reduction of sodium fluoride effects which reversely affect the albino rat haematological parameters especially the total WBC's count with a recorded difference of 24.4 and 12.10 respectively as compared with $48.24 \%$ difference caused by the administration of sodium fluoride alone in the second group. Reduction effect was also noticed on the other haematological parameters such as RBC count with a recorded.

\subsection{Histopathological changes}

The previous biochemical results were reinforced by the histopathological results. Oral administration of Olive oil at $(5 \mathrm{ml} / \mathrm{kg}$ body weight for 14 days) showed no pathological alterations on liver, Kidney tissues. 
Our results clearly showed the adverse effect in rats induced by intramuscular injection of cefotaxime for 14 days on the liver, which appear in the form of, inflammatory cells infiltration with dilatation in the portal vein, as well as periductal fibrosis with inflammatory cells infiltration surrounding the bile ducts, There was diffuse kupffer cells proliferation in between the hepatocytes all over the parenchyma , Focal necrosis was detected in the parenchyma, associated with focal degeneration and necrobiotic changes in the area hepatocytes at the periphery of the lobules, Kidney of cefotaxime treated rats showed that The cortical blood vessels were congested while the corticomedullary portion showed degeneration and necrobiotic changes in the lining epithelium of the tubules .All these observed result was in harmony with that detected by (Jazaa 2017) who observed histological changes in liver and kidney of cefotaxime treated rats that showed vacuolar degeneration of the hepatocytes with the appearance of infiltration of the lymphocytes and necrosis of the hepatocytes. The kidney showed inter-tubular haemorrhage with necrosis of some renal tubules.

\section{Conclusion}

It is concluded olive oil has an ameliorating effect which minimizes the hepato-renal toxicity induced by cefotaxime, there by suggesting its use as a potent hepatic and renal protective agent.

\section{References}

[1] ABBAS, M. T., ALI, A. J., ABBAS, I. S., METAB, N., HADI, H. N., ABBAS, K. S., \& Jalal, H. (2015). Effect of Olea Europea (Olive oil) on gentamicin induced hepatorenal toxicity in male rats. karbala journal of pharmaceutical sciences, (10).

[2] Abd El Fadil, H., Alim A, A. F., A, R. Y., Gad, A. M., \& A, A. Y. (2018). Ameliorative Role of Curcumin on Liver of Rats Treated with Gentamicin, Cefotaxime and Metronidazole. The Pharmaceutical and Chemical Journal,5(5),65-72.www.tpcj.org

[3] Abd, H., Fadil, E., A, A. A. F., El-garhy, A. M., \& Ahmady, Y. (2016). Histopathological and Histochemical effects of Fresh Garlic Homogenate on reno-hepatic alterations in rats treated with Gentamicin, Cefotaxime and Metronidazole. 6(5), 13-19.

[4] Abed, R. M. (2017). The effect of olive oil on ibuprofen induced Renal toxicity in female rats. karbala journal of pharmaceutical sciences, $8(13)$, $167-177$

[5] Ahmad, S., Begum, R., \& Kumar, M. (2015). Study of renal parameter changes by intraperitoneal injection of amikacin and cefotaxime in albino rats. International Journal of Basic \&Clinical Pharmacology, 4(2), 1. https://doi.org/10.5455/2319-2003.ijbcp20150405.

[6] Aziz, I. A., \& Masad, A. (2013). Fluoride-induced Hematological and Biochemical Changes in Albino Rat. The Therapeutic Action of Vitamin C and Olive Oil on Fluoride Effects. 50-31. مجلة جامعة الأزهر- غزة.

[7] Banchroft, J.D.; Stevens, A. And Turner, D.R. (1996). theory and practice of histological techniques. Fourth Ed. Churchil Livingstone, New York , London, San Francisco, Tokyo.

[8] Birben, E., Sahiner, U. M., Sackesen, C., Erzurum, S., \& Kalayci, O. (2012). Oxidative stress and antioxidant defense. The World Allergy Organization journal, 5(1), 9-19. https://doi.org/10.1097/WOX.0b013e3182439613.

[9] Bitler, C. M., Viale, T. M., Damaj, B., \& Crea, R. (2005). Hydrolyzed olive vegetation water in mice has anti-inflammatory activity. The Journal of nutrition, 135(6), 1475-1479. https://doi.org/10.1093/jn/135.6.1475.

[10] Chairman, N. W. (1983). A reference method for measurement of alkaline phosphatale activity in human serum study group on alkaline phosphtase Clin. Chem, 29, 751. https://doi.org/10.1093/clinchem/29.5.751.

[11] El Bohi KM, Ghoniem MH, Azab HH, Ali H, Farag MR. (2020). Extra virgin olive oil enhances the hepatic antioxidant defense and inhibits cytogenotoxic effects evoked by 5-hydroxymethylfurfural in mice. Environmental Science and Pollution Research International. 27(11):11882-11891 https://doi.org/10.1007/s11356-020-07659-x.

[12] El-Maddawy -Zeynab and Bogzil, S.H. (2015). Adverse effects of cefotaxime sodium in comparison with ceftiofur sodium in male rats. , Int. Pharm. Pharm Sci. J; vol 7,(4)p:(343-346).

[13] Follin, O.Z. (1934). Colorimetric determination of creatinine Phs. Chem. 268:228.

[14] Fujiwaki, T., Yoshikawa, T., Urashima, R., \& Ishioka, C. (2008). Drug rash with eosinophilia and systemic symptoms induced by cefotaxime and ampicillin. Pediatrics international: official journal of the Japan Pediatric Society, 50(3), 406-408. https://doi.org/10.1111/j.1442200X.2008.02603.X.

[15] Ghorbel, I., Elwej, A., Jamoussi, K., Boudawara, T., Kamoun, N. G., \& Zeghal, N. (2015). Potential protective effects of extra virgin olive oil on the hepatotoxicity induced by co-exposure of adult rats to acrylamide and aluminum. Food \& function, 6(4), 1126-1135. https://doi.org/10.1039/C4FO01128G.

[16] Giguère,S.; Prescott, J. F. and Dowling, P. M.(2013). Antimicrobial therapy in veterinary medicine, John Wiley and Sons, Inc.5th edition pp.165. https://doi.org/10.1002/9781118675014.

[17] Jazaa, A. A. (2017). Effect of Cefotaxime Administration on the kidney, liver and Lung of Swiss white Mice (mus musculus). 22(6), 1-7.

[18] Kathleen, G. (2004). Newer antibiotics: cefepime. Neo Reviews Vol. 5 No. 9

[19] Khayyat, L. I. (2016). Protective effects of extra virgin olive oil against paracetamol-induced liver toxicity in Wistar albino rats. 40(June), 30-40.

[20] Lee, D. H., Han, D. H., Nam, K. T., Park, J. S., Kim, S. H., Lee, M., Kim, G., Min, B. S., Cha, B. S., Lee, Y. S., Sung, S. H., Jeong, H., Ji, H. W., Lee, M. J., Lee, J. S., Lee, H. Y., Chun, Y., Kim, J., Komatsu, M., Lee, Y. H., ... Bae, S. H. (2016). Ezetimibe, an NPC1L1 inhibitor, is a potent Nrf2 activator that protects mice from diet-induced nonalcoholic steatohepatitis. Free radical biology \& medicine, 99, 520-532. https://doi.org/10.1016/j.freeradbiomed.2016.09.009.

[21] Magdaleno, F., Blajszczak, C. C., \& Nieto, N. (2017). Key Events Participating in the Pathogenesis of Alcoholic Liver Diease.Biomolecules,7(1),9. https://doi.org/10.3390/biom7010009.

[22] March, W.H., Fingerhut, B. and Miller, H. (1965). Clinical chemistry, 11:624-627. https://doi.org/10.1093/clinchem/11.6.624.

[23] Martín, M. A., Ramos, S., Granado-Serrano, A. B., Rodríguez-Ramiro, I., Trujillo, M., Bravo, L., \& Goya, L. (2010). Hydroxytyrosol induces antioxidant/detoxificant enzymes and Nrf2 translocation via extracellular regulated kinases and phosphatidylinositol-3-kinase/protein kinase B pathways in HepG2 cells. Molecular nutrition \& food research, 54(7), 956-966. https://doi.org/10.1002/mnfr.200900159.

[24] Masella, R., Di Benedetto, R., Varì, R., Filesi, C., \& Giovannini, C. (2005). Novel mechanisms of natural antioxidant compounds in biological systems: involvement of glutathione and glutathione-related enzymes. The Journal of nutritional bichemiry,16(10), 577586. https://doi.org/10.1016/j.jnutbio.2005.05.013.

[25] Mohammadian, M., Mianabadi, M., Zargari, M., Karimpour, A., Khalafi, M., \& Amiri, F. T. (2018). Effects of Olive Oil supplementation on Sodium Arsenate-induced Hepatotoxicity in Mice. International journal of preventive medicine, 9, 59. https://doi.org/10.4103/ijpvm.IJPVM_165_18.

[26] Mohammed, E., Hashem, K., \& Rheim, M. (2014). Biochemical study on the impact of Nigella sativa and virgin olive oils on cadmium-induced nephrotoxicity and neurotoxicity in rats. Journal of Investigational Biochemistry, 3(2), 71. https://doi.org/10.5455/jib.20140716041908.

[27] Natt, M. and Herrick, A. (1952). A new blood diluent for counting the erythrocytes and leukocytes of the chicken. Poultry Science; 31(4): 735-738. https://doi.org/10.3382/ps.0310735.

[28] Necib, Y., Bahi, A., Zerizer, S., Abdennour, C., \& Boulakoud, M. S. (2014). Protective effect of virgin olive oil (Olea europea L.) against oxidative damage induced by mercuric chloride in rat Albinos Wistar. Journal of Stress Physiology \& Biochemistry, 10 (1), 45-58. 
[29] O'Connor, K. A., Kingston, M., O'Donovan, M., Cryan, B., Twomey, C., \& O'Mahony, D. (2004). Antibiotic prescribing policy and Clostridium difficile diarrhoea. QJM: monthly journal of the Association of Physicians, 97(7), 423-429. https://doi.org/10.1093/qjmed/hch076.

[30] Ognjanovic, B. I., Pavlovic, S. Z., Maletic, S. D., Zikic, R. V., Stajn, A. S., Saicic, Z. S., \& Petrovic, V. M. (1999). Effect of olive oil on the haematological and metabolic values in blood and plasma of rats after acute cadmium intoxication. Acta Biologica Iugoslavica. Serija C.

[31] Pirozzi, C., Lama, A., Simeoli, R., Paciello, O., Pagano, T. B., Mollica, M. P., Di Guida, F., Russo, R., Magliocca, S., Canani, R. B., Raso, G. M., Calignano, A., \& Meli, R. (2016). Hydroxytyrosol prevents metabolic impairment reducing hepatic inflammation and restoring duodenal integrity in a rat model of NAFLD. The Journal of nutritional biochemistry, 30, 108-115. https://doi.org/10.1016/j.jnutbio.2015.12.004.

[32] Plosker, G. L., Foster, R. H., \& Benfield, P. (1998). Cefotaxime. A pharmacoeconomic review of its use in the treatment of infections. PharmacoEconomics,13(1 Pt 1), 91-106. https://doi.org/10.2165/00019053-199813010-00009.

[33] REITMAN, S., \& FRANKEL, S. (1957). A colorimetric method for the determination of serum glutamic oxalacetic and glutamic pyruvic transaminases. American journal of clinical pathology, 28(1), 56-63. https://doi.org/10.1093/ajcp/28.1.56.

[34] Rivkin AM. (2005). Hepatocellular enzyme elevations in a patient receiving ceftriaxone. American Journal of Health-system Pharmacy: AJHP: Official Journal of the American Society of Health-system Pharmacists. Oct;62(19):2006-2010. https://doi.org/10.2146/ajhp040452.

[35] Soliman, A. M. (2015). HEPATO-RENAL EFFECTS OF CEFOTAXIME IN ALBINO RATS. International Journal of Pharmacy and and Pharmaceutical Sciences, 7(11), 312-315. Retrievedfrom. https://innovareacademics.in/journals/index.php/ijpps/article/view/8498

[36] Sweetman, S. C. (2009). Martindale the complete drug reference. London: Pharmaceutical Press.

[37] Thomas, S.R. (2005). Modelling and simulation of the kidney. Journal of Biological Physics and Chemistry; 5:70-83.

[38] van Zanten, A. R., Oudijk, M., Nohlmans-Paulssen, M. K., van der Meer, Y. G., Girbes, A. R., \& Polderman, K. H. (2007). Continuous vs. intermittent cefotaxime administration in patients with chronic obstructive pulmonary disease and respiratory tract infections: pharmacokinetics/pharmacodynamics, bacterial susceptibility, and clinical efficacy. British journal of clinicalpharmacology,63(1),100-109. https://doi.org/10.1111/j.1365-2125.2006.02730.x.

[39] Weydert,C.G and Cullen,J.J ( 2010). Measurment of superoxide dimutase, catalase and glutathione peroxidase in cultured cells and tissues. natural Protocola 5:51-66 https://doi.org/10.1038/nprot.2009.197.

[40] Williams, C. S., Shamdas, G. J., Lo, T. S., \& Koo, J. M. (2009). A fatal case of ceftriaxone-induced autoimmune hemolytic anemia. Hosp Physician, 45(5), 21-5.

[41] Zhao, B., Ma, Y., Xu, Z., Wang, J., Wang, F., Wang, D., Pan, S., Wu, Y., Pan, H., Xu, D., Liu, L., \& Jiang, H. (2014). Hydroxytyrosol, a natural molecule from olive oil, suppresses the growth of human hepatocellular carcinoma cells via inactivating AKT and nuclear factor-kappa B pathways. Cancer letters, 347(1), 79-87. https://doi.org/10.1016/j.canlet.2014.01.028. 